\title{
Analisis Faktor-Faktor Yang Mempengaruhi Keputusan Membeli Komoditi Pertanian Di Pasar Tradisional Kepanjen Malang
}

\section{Analysis Of Factors Affecting Decision To Buy Agricultural Commodities In The Traditional Market Of Kepanjen Malang}

\author{
Indra Bayu' ${ }^{1}$, Jabal Tarik Ibrahim², Ary Bakhtiar ${ }^{3}$, Fithri Mufriantie ${ }^{4}$ \\ ${ }^{1,23}$ Universitas Muhammdiyah Malang \\ ${ }^{4}$ Universitas Muhammdiyah Bengkulu \\ bayuindra942@gmail.com
}

\begin{abstract}
ABSTRAK
Pasar merupakan tempat bertemunya penjual dan pembeli yang sedang melakukan transaksi, baik barang maupun jasa. Salah satu barang yang menjadi pokok kegitan jual beli adalah komoditas pertanian sebagai sumber utama bahan pangan. Pasar yang paling banyak dijumpai dan diminati salah satunya adalah pasar tradisional. Tujuan penelitian ini untuk Menganalisis secara bersama sama pengaruh faktor produk, pendapatan, kuantitas, kualiatas tempat, pelayanan terhadap keputusan membeli komoditas pertanian dipasar tradisional Kepanjen dan faktor manakah yang paling dominan. Teknik pengambilan sampel menggunaan accidental sampling, dengan jumlah responden 88 dan regresi linear berganda. Hasil penelitian karakteristik responden didominasi oleh jenis kelamin perempuan dengan rentang usia 36-55, memiliki tanggungan jumlah keluarga 3-4 orang, pendidikan smp dan dengan pendapatan rentang 2.500.000 - 4.000.000. Hasil analilis uji F didapatkan nilai signifikasi sebesar 0,119 yang artinya terdapat pengaruh secara bersama sama pada variabel pendapatan, kuantitas, kualiatas tempat, pelayanan terhadap keputusan membeli komoditas pertanian dipasar tradisional Kepanjen. Sedangkan pada uji t didapat dua variabel yang memiliki nilai kurang dari 0,15 yaitu variabel kuantitas 0,140 dan variabel pelayanan 0,016 yang artinya berpengaruh secara parsial dan yang paling dominan adalah variabel pelayanan berpengaruh terhadap keputusan membeli komoditas pertanian dipasar tradisional Kepanjen Malang.

Kata kunci: Keputusan membeli; pasar tradisional; komoditi pertanian
\end{abstract}

\begin{abstract}
A market is a meeting place for sellers and buyers who are conducting transactions, both goods, and services. One of the main items for buying and selling activities is agricultural commodities as the main source of food. One of the most found and popular markets is the traditional market. The purpose of this research is to analyze together the influence of product factors, income, quantity, quality of place, service on the decision to buy agricultural commodities in the traditional Kepanjen market, and which factors are the most dominant. The sampling technique used accidental sampling, with the number of respondents 88 and multiple linear regression. The results of the research are the characteristics of the respondents are dominated by the female gender, ranging in age from 36-55, having a family of 3-4 people, junior high school education, and with an income ranging from 2,500,000 to 4,000,000. The results of the $F$ test analysis obtained a significance value of 0.119, which means that there is a joint influence on the variables of income, quantity, quality of place, service on the decision to buy agricultural commodities in the traditional Kepanjen market. While the t-test obtained two variables that have a value less than 0.15 , namely the quantity variable 0.140 and the service variable 0.016 which means that it is partially influential and the most dominant is the service variable which influences the decision to buy agricultural commodities in the traditional market of Kepanjen Malang.
\end{abstract}

Keywords: Buying decision; traditional markets; agricultural commodities

\section{PENDAHULUAN}

Semakin banyaknya jumlah manusia semakin banyak pula jumlah kebutuhan yang diinginkan. Salah satu kebutuhan mendasar yang harus dipenuhi adalah kebutuhan akan pangan. Kebutuhan pangan sebagian besar didapat dari hasil pertanian sebagian lagi dari hasil peternakan dan perikanan. Untuk Memenuhi kebutuhan tersebut masyarakat umumnya berbelanja melakukan transaksi jual beli dipasar. namun di era sekarang sangat banyak alternatif untuk berbelanja seperti berbelanja secara online, berbelanja dipasar modern pasar tradisional dan pedagang keliling dari ke empat tempat berbelanja tersebut akankah pasar tradisional mampu bersaing diera modern saat ini. 
Pasar tempat bertemunya antara penjual dan pembeli barang atau jasa yang ditawarkan untuk dijual, dan terjadinya perpindahan kepemilikan, Noor \& Ikasari, (2010). Pasar saat ini di bagi menjadi dua macam yaitu pasar tradisional dan pasar modern. Pasar tradisional dan modern tentu saja memiliki ciri ciri serta kekurangan dan kelebihan masing-masing. Pasar tradisional merupakan pasar yang biasanya ada pada suatu desa, pasar tradisional biasanya memiliki ciri ciri tempat atau bangunan yang kurang tersusun rapi atau cenderung berantakan dan bisa dikatakan kumuh. Pasar tradisional mempunyai banyak kekurangan dan kelemahan, seperti kumuh dan kotor, kemasan produk yang dijual kurang menarik. Namun masih banyak konsumen yang melakukan pembelian dipasar tradisional. Hal ini karena berbagai alasan seperti: harga yang terjangkau, adanya proses tawarmenawar, keberagaman produk, area penjualan yang luas serta kondisi barang masih segar tanpa pendingin di lemari es (Saodah \& Malia, 2017).

Pasar tradisional tempat bertemunya penjual dan pembeli yang dapat mengadakan tawar menawar secara langsung, Arianty, (2013). Tawar menawar didalam pasar tradisional sangat umum terjadi sebelum adanya kesepakatan membeli barang. Pasar tradisional banyak menjual berbagai aneka kebutuhan pokok sehari hari seperti bahan bahan makanan sayur sayuran, ikan laut maupun tawar, buah buahan, barang barang elektronik, maupun jasa.

Pasar modern merupakan tempat dimana penjual dan pembeli tidak bertransaksi secara langsung melainkan pembeli melihat label harga yang ada di luar kemasan produk, berada dalam bangunan dan pelayanannya dilakukan secara mandiri (swalayan) atau dilayani oleh pramuniaga, Eliza, Sayamar, \& Kaswita, (2011). Pasar yang biasanya ada pada wilayah perkotaan, pasar modern biasanya didirikan oleh perusahaan perusahaan swasta maupun suatu koperasi yang kapasitasnya besar. Bentuk pasar modern saat ini yang bisa kita jumpai seperti mal dan supermarket. Tinggi kenyamanan, kemudahan bertransaksi, serta kualitas produk merupakan hal yang sangat diutamakan.

Kepanjen salah satu kecamatan terbesar yang ada di kabupaten malang https://doi.org/10.32528/agribest.v4i2.3547 dengan luas wilayah $44.68 \mathrm{~km}^{2}$. Wilayah yang luas tersebut sebagian besar merupakan area persawahan yang banyak ditanami berbagai macam komoditi pertanian, sebagian besar hasil dari panen tersebut dijual dipasar dalam kecamatan, yaitu pasar tradisional Kepanjen. Pasar tradisonal Kepanjen menjadikan salah satu pusat berbelanja kebutuhan pangan di antara pasar pasar tradsional dan pasar modern yang lain.

Perilaku konsumen merupakan suatu fenomena yang sangat unik untuk dipelajari dan diteliti terlebih saat ini ada beberapa alternatif pilihan yang menjual berbagai komoditas pertanian. Keputusan pembelian merupakan keputusan konsumen mengenai preferensi atas merek yang ada di dalam kumpulan pilihan. Banyak faktor dapat mempengaruhi perilaku konsumen untuk melakukan pembelian. Pemahaman mengenai perilaku konsumen merupakan kunci kesuksesan utama bagi para pemasar. Terdapat tiga alasan mengapa studi perilaku konsumen sangat penting. Menurut (Sunarto, 2018) mengatakan bahwa perilaku konsumen adalah studi unit dan proses pembuatan keputusan yang terlibat dalam menerima, menggunakan dan penentuan barang, jasa, dan ide.

Berdasarkan latar belakang masalah yang telah dijelaskan, maka permasalahan yang akan di teliti adalah meliputi, 1) Adakah pengaruh faktor produk, pendapatan, kuantitas, tempat, pelayanan dan kualitas secara bersama sama terhadap keputusan membeli komoditas pertanian dipasar tradisional Kepanjen 2) Adakah pengaruh faktor tempat atau lokasi terhadap keputusan membeli komoditas pertanian dipasar tradisional Kepanjen? 3) Faktor manakah dari produk, pendapatan, kuantitas, tempat, pelayanan dan kualitas yang paling besar mempengaruhi keputusan membeli komoditas pertanian di pasar tradisional Kepanjen?

Berdasarkan dengan rumusan masalah yang ada pada penelitian ini, maka tujuan penelitian adalah: 1) Menganalisis secara bersama sama pengaruh faktor produk, pendapatan, kuantitas, kualiatas tempat, pelayanan terhadap keputusan membeli komoditas pertanian dipasar tradisional Kepanjen. 2) Menganalisis faktor tempat atau lokasi terhadap keputusan membeli komoditas pertanian dipasar tradisional 
Kepanjen. 3) Menganalisis faktor manakah diantara faktor produk, pendapatan, kualitas, tempat, pelayanan dan pelayanan yang memberikan pengaruh paling besar terhadap keputusan membeli komoditas pertanian di pasar tradisonal Kepanjen.

Adapun manfaat dari penelitian ini adalah sebagai berikut: 1) Sebagai pembelajaran untuk memahami perilaku konsumen, sehingga berguna meningkatkan pelayan dan kualitas pasar. 2) Sebagai sarana menambah wawasan, pengetahuan serta memecahkan masalah berdasarkan fakta yang ada bagi penulis.

\section{METODE PENELITIAN \\ Jenis Data}

Kegiatan penelitian ini menggunakan data primer. Data primer merupakan data yang diperoleh dari sumber utama responden yang berkaitan. Data primer didapat dari melalui pengisian kuesioner dan wawancara. Data yang diambil merupakan pernyataan dari keputusan membeli yang dipengaruhi oleh faktor pendapatan, produk, kuantitas, tempat, pelayanan dan kualitas dipasar tradisional. Variabel dan indikator yang digunakan dalam penelitian ini disajikan pada tabel 1 .

Tabel 1. Variabel Dan Indikator Penelitian

\begin{tabular}{clll}
\hline No & \multicolumn{1}{c}{ Variabel } & & \\
\hline 1 & Pendapatan & & \\
2 & Produk & a. Produk hasil pertanian \\
& & b. Keberagaman produk \\
3 & Kuantitas & a. Membeli dengan jumlah banyak \\
4 & Tempat & b. Membeli dengan jumlah sedikit \\
& & a. Lokasi pasar \\
5 & Pelayanan & b. Menarik dan tertata \\
6 & Kualitas & a. Penjual yang ramah \\
& & b. Sarana umum pasar \\
7 & Keputusan membeli & a. Kualitas baik \\
\end{tabular}

\section{Waktu dan Tempat}

Penelitian dilaksanakan pada Bulan maret 2020 yang dilakukan dipasar tradisional Kepanjen Kabupaten Malang. Pemilihan lokasi penelitian ditentukan menggunakan metode purposive sampling, yaitu dimana penentuan lokasi dilakukan secara sengaja atas pertimbangan tertentu. Pertimbangan yang digunakan untuk menentukan lokasi penelitian adalah karena pasar ini merupakan pasar utama yang di tuju oleh masyarakat, dimana Pasar Tradisional Kepanjen ini menjual hasil komoditas pertanian yang sebagian besar berasal dari hasil pertanian di wilayah kepanjen itu sendiri. Kepanjen merupakan kecamatan yang memiliki lahan pertanian yang cukup besar, menurut data BPS lahan pertanian yang ada di Kecamatan Kepanjen berjumlah sebesar 2.152 hektar. Luas lahan tersebut di manfaatkan petani untuk menanam padi, jagung, terong, kacang-kacangan dan masih banyak lainya. Jumlah hasil produksi terbesar ada pada beras sebesar 21.219ton pada tahun 2018. Hasil pertanian tersebut dipasarkan didalam Kecamatan dan diluar Kecamatan.

\section{Teknik Pengambilan Sampel}

Pengambilan sampel yang dilakukan pada penelitian ini dilakukan dengan menggunakan metode accidental sampling. Accidental sampling dipilih karena situasi peneliti tidak mengetahui secara pasti jumlah populasi yang ada (Ibrahim, 1999). Responden dalam penelitian ini adalah seluruh masyarakat, yang pernah membeli dan mengonsumsi produk dari komoditas pertanian dipasar tradisional yang ada di Kecamatan Kepanjen Kabupaten Malang. Teknik pengambilan sample menggunakan rumus Hair, (2006) menyatakan bahwa ukuran jumlah sample minimum berjumlah 5 observasi untuk setiap estimated parameter dan maksimal 10 observasi dari setiap estimated parameter. Penelitian ini memiliki jumlah indikator 11 indikator. Rumus yang digunakan yakni n x 5 sampai 10. Penelitian ini menggunakan, jumlah sample $=$ jumlah indikator $\times 8=11 \times 8=88$ sehingga jumlah sample yang dibutuhkan berjumlah 88 responden. 


\section{Teknik Pengumpulan Data}

Penelitian ini menggunakan data primer data yang diambil dari sumber utama yang didapatkan secara langsung. Teknik pengumpulan data menggunakan metode wawancara langsung dengan responden yang datang untuk membeli produk komoditas pertanian dengan menggunakan daftar pertanyaan kuesioner.

\section{Kuesioner}

Merupakan cara pengambilan data yang dibuat oleh peneliti yang tertuang di kertas yang berisi pertanyaan. Pengisian kuesioner dilakukan oleh responden. Kuesioner penelitian ini menggunakan skala likert

2. Wawancara

Teknik ini digunakan untuk memperoleh data menggunakan acuan daftar pertanyaan tertulis (kuesioner) melalui percakapan langsung dengan responden. Teknik yang demikian disebut dengan wawancara terstruktur. Tujuannya adalah untuk memperoleh informasi yang akurat melalui respon langsung dari responden.

3. Dokumentasi

Teknik ini digunakan untuk memperoleh data melalui bentuk tulisan maupun gambar. Proses wawancara dan pengisian kuesioner termasuk dalam kegiatan mendokumentasikan data. Dokumentasi yang dilakukan diharapkan mampu memberikan penjelasan bagi pembaca akan situasi dan kondisi ketika turun lapang.

\section{Uji Instrumen Penelitian}

Arikunto (2013) menjelaskan bahwa instrumen penelitian adalah alat atau fasilitas yang digunakan oleh peneliti dalam mengumpulkan data agar mempermudah pekerjaannya dan hasilnya lebih baik, dalam arti lebih cermat, lengkap, dan sistematis sehingga lebih mudah di olah instrumen pengukuran variabel dalam penelitian kuantitatif harus memenuhi beberapa persyaratan agar menghasilkan data pengukuran variabel penelitian yang akurat. Persyaratan yang paling banyak dikemukakan oleh para ahli dan dianggap syarat baku adalah validitas dan reliabilitas.

Menurut Suliyanto (2005) Validitas menunjukkan sejauh mana ketepatan dan kecermatan suatu alat ukur dalam melakukan fungsi ukurnya. Validitas adalah suatu ukuran dapat dianggap valid apabila mampu https://doi.org/10.32528/agribest.v4i2.3547 mengukur apa yang diinginkan Uji validitas berguna untuk mengetahui apakah terdapat pertanyaan pertanyaan yang dianggap tidak relevan pada kuesioner sehingga harus dilakukan perbaikan penyusunan kuesioner.

Reliabilitas adalah alat untuk mengukur suatu kuesioner yang merupakan indikator dari variabel. Suatu kuesioner dikatakan reliabel atau handal jika jawaban seseorang terhadap pertanyaan adalah konsisten atau stabil dari waktu ke waktu (Ghozali, 2005) . Uji reliabilitas menggunakan koefisien Cronbach's Alpa dengan bantuan SPSS. Uji reliabilitas harus dilakukan hanya pada pertanyaan pertanyaan yang sudah memenuhi uji validitas dan yang tidak memenuhi maka tidak perlu diteruskan untuk uji reliabilitas. Pengambilan keputusan yakni menggunakan nilai $r$ alpha yang dibandingkan dengan $r$ tabel. Syarat pengambilan keputusan yakni apabila nilai $r$ alpha > $\mathrm{r}$ tabel maka kesimpulannya data reliabel dan apabila nilai $\mathrm{r}$ alpha $<\mathrm{r}$ tabel maka kesimpulannya data tidak reliabel.

Menurut Perdana (2016) Uji asumsi klasik adalah persyaratan statistik yang harus dipenuhi pada analisis regresi berganda yang berbasis ordinary least square. Perdana juga memberikan penjelasan terkait uji normalitas data, uji multikolinearitas dan uji heteroskedastisitas sebagai berikut.

Uji normalitas digunakan untuk melihat apakah variabel independ seperti faktor produk, pendapatan, kuantitas, tempat, pelayanan, dan kualitas maupun variabel dependen berupa keputusan membeli mempunyai distribusi normal atau tidak. Model regresi yang baik adalah distribusi data normal atau mendekati normal.

Uji multikolinearitas adalah alat uji model regresi yang digunakan untuk menemukan adanya korelasi antar variable bebas (independen). Model regresi yang baik seharusnya tidak terjadi korelasi diantara variable independen. Uji multikolinearitas dapat dilakukan dengan uji regresi, dengan nilai patokan VIF (Variance Inflation Factor) dan nilai Tolerance. Kriteria yang digunakan adalah :

1. Jika nilai VIF di sekitar angka 1-10, maka dikatakan tidak terdapat masalah multikolinearitas.

2. Jika nilai Tolerance $\geq 0.10$, maka dikatakan tidak terdapat masalahmulti kolinearitas. 
Uji heterokedastisitas adalah alat uji model regresi digunakan untuk mengetahui ketidak samaan variance dari residual satu observasi ke observasi yang lainnya. Jika variance dari residual satu pengamatan ke pengamatan lain tetap, maka disebut Homokedastisitas dan jika berbeda disebut Heterokedastisitas. Model regresi yang baik adalah yang homokedastisitas atau tidak terjadi masalah heterokedastisitas.

\section{Analisis Data}

Metode analisi yang digunakan dalam penelitian ini adalah analisis Analisis data yang digunakan pada penelitian ini adalah deskripstif serta statistik yang berupa Regresi Linear Berganda dengan menggunakan bantuan software spss. Metode deskriptif adalah metode penelitian yang digunakan untuk mendeskripsikan masalah pada masa sekarang dan yang sedang berlangsung, memiliki tujuan untuk menggambarkan apa saja yang terjadi sesuai keadaan pada saat penelitian. Menurut (Sudjana, 2001) mendefinisikan penelitian deskriptif merupakan penelitian yang berusaha mendeskripsikan suatu gejala, peristiwa, kejadian yang terjadi pada saat sekarang.

Analisis regresi linier berganda merupakan suatu teknik statistika yang digunakan untuk mencari persamaan regresi yang bermanfaat untuk meramal nilai variabel dependen berdasarkan nilai-nilai variabel independen dan mencari kemungkinan kesalahan dan menganalisa hubungan antara satu variabel dependen dengan dua atau lebih variabel independen baik secara simultan maupun parsial. Menurut Sugiyono (2017) Analisis regresi linear berganda digunakan oleh peneliti, bila peneliti meramalkan bagaimana keadaan (naik turunnya) variabel dependen (kriterium), bila dua atau lebih variabel independen sebagai faktor predictor dimanipulasi (dinaik turunkan nilainya. Jadi analisis regresi berganda akan dilakukan bila jumlah variabel independennya minimal 2 . Analisis tersebut digunakan untuk mengetahui seberapa besar pengaruh variabel bebas yaitu: produk (X1), pendapatan (X2), kuantitas (X3), tempat (X4), pelayanan (X5), kualitas (X6). Terhadap variabel terikat yaitu keputusan membeli (Y). Persamaan regresi linier berganda adalah sebagai berikut: $\mathrm{Y}=\alpha+\mathrm{b}_{1} \mathrm{X}_{1}+\mathrm{b}_{2} \mathrm{X}_{2}+$ $b_{3} X_{3}+b_{4} X_{4}+b_{5} X_{5}+b_{6} X_{6}$

Dimana:

$\mathrm{Y}=$ Variabel dependen (keputusan membeli) $\mathrm{a}=$ konstanta

$b_{1-6}=$ koefisien regresi variabel X1 sampai $\mathrm{X} 6$

$\mathrm{X}_{1}=$ variabel produk

$\mathrm{X}_{2}=$ variabel pendapatan

$\mathrm{X}_{3}=$ variabel kuantitas

$\mathrm{X}_{4}=$ variabel tempat

$\mathrm{X}_{5}=$ variabel pelayan

$\mathrm{X}_{6}=$ variabel kualitas

Hasil persaman regresi yang diperoleh kemudian dilakukan pengujian untuk mengetahui apakah koefisien regresi yang diperoleh mempunyai pengaruh yang signifikan baik secara parsial dan secara simultan serta untuk mengetahui seberapa besar pengaruhnya. Pengolahan data dengan regresi perlu dilakukan beberapa pengujian antara lain

\section{Uji F Atau Uji Simultan}

Menurut Perdana (2016) uji statistik f pada dasarnya menunjukkan apakah variabel independent yang berupa produk, pendapatan, kuantitas, tempat, pelayanan, dan kualitas yang dimasukkan dalam model mempunyai pengaruh secara bersama - sama terhadap variabel dependen yaitu keputusan membeli komoditas pertanian yang hendak diuji. Perdana juga memberikan penjelasan terkait uji t dan adj $\mathrm{r}$ sebagai berikut.

2. Uji $\mathrm{t}$

Pengujian secara individual (uji-t) yaitu pengujian koefisien regresi secara parsial dengan menentukan formula statistik yang akan diuji. Untuk mengetahui apakah suatu variabel independent faktor produk berpengaruh nyata atau tidak terhadap variabel dependent yaitu keputusan membeli komoditas pertanian.

3. Uji Adj R

Uji Adj R digunakan untuk melihat layak atau tidak suatu penelitian yang dilakukan dengan melihat pengaruh variabel independent terhadap variabel dependent. Koefisien determinasi R2 digunakan untuk mengetahui berapa persen variasi variabel dependent dapat dijelaskan oleh variasi variabel independen. Nilai R2 ini terletak antara 0 dan 1. Bila nilai R2 mendekati 0 berarti sedikit sekali variasi variabel dependen yang diterangkan oleh variabel independen. Jika ternyata dalam perhitungan 
nilai R2 sama dengan 0 maka ini menunjukkan bahwa variabel dependen tidak bisa dijelaskan oleh variabel independent.

\section{HASIL DAN PEMBAHASAN Analisis Deskriptif}

Sesuai dengan tujuan analisis deskriptif yaitu untuk memberikan gambaran mengenai hasil penelitian secara umum, bagaimana karakteristik subyek penelitian sehubungan dengan variabel-variabel yang diteliti. Menurut Sugiyono (2017) Analisis deskriptif digunakan untuk menganalisis data dengan cara mendeskripsikan atau menggambarkan data yang telah diperoleh dengan sebagaimana adanya tanpa bermaksud membuat kesimpulan yang berlaku untuk umum atau generalisasi. Dasar yang digunakan untuk melakukan analisis deskriptif adalah skor rata-rata setiap indikator penelitian. Skala likert merupakan alat ukur yang digunakan untuk menggambarkan jawaban atas suatu penelitian yang dilakukan. Berikut merupakan analisis deskriptif penelitian ini.

\section{Produk}

Produk merupakan barang yang dihasilkan untuk dijual, produk yang dimaksud dalam penelitian ini merupakan hasil pertanian yang dijual dipasar tradisonal. Menurut Kurriwati, (2016) kualitas produk merupakan hal yang sangat penting yang harus diusahakan oleh perusahan atau produsen jika ingin produk yang dihasilkan bersaing dipasar untuk memuaskan dan memenuhi kebutuhan keinginan konsumen. Terdapat sejumlah 2 indikator, yang didalamnya terdapat 10 pertanyaan yang digunakan dalam penelitian ini untuk mengukur variabel produk. Berikut skor rata rata indikator yang disajikan pada tabel 10 .

Tabel 2. Analisis Produk

\begin{tabular}{ccc}
\hline No & Indikator & Rata rata skor jawaban \\
\hline 1. & Produk hasil pertanian & 4 \\
2. & Keberagaman produk hasil pertanian & 4 \\
\hline
\end{tabular}

Sumber: Data Primer Diolah, Tahun 2020

Tabel 10 menunjukan bahwa rata rata skor dari kedua indikator mendapat nilai 4 . Nilai rata rata skor menunjukan bahwa dari 88 responden penelitian, jawaban terbesar mereka atas pertanyaan dari indikator diatas adalah (setuju), atas dasar penilaian dari koesioner skala likert yang didapat dari rata rata jawaban responden. Artinya responden mengakui (setuju) bahwa produk hasil pertanian yang dijual dipasar tradisional kepanjen berkualitas baik, begitu juga dengan indikator keberagaman produk hasil pertanian. Variabel produk dalam penelitian ini mendapat nilai positif dari hasil koesiner skala likert, namun produk hasil pertanian yang baik jika lokasi pasarnya tidak strategis akan membuat konsumen enggan untuk membelinya. Penelitian ini memiliki kesamaan dengan penelitian yang dilakukan oleh Walukow A.L.P \& Mananeke L, (2014) dengan menggunakan variabel produk.

\section{Kualitas}

Kualitas merupakan baik atau buruknya suatu pelayan dan juga dari produk yang di tawarkan. Menurut Idris, Sari, Wulandari, \& U, (2016) kualitas merupakan faktor yang dapat meningkatkan daya saing dari suatu produk. Kualitas dari penelitian adalah kualitas produk, serta pelayanan dari pedagang yang diberikan kepada konsumen yang berbelanja dipasar tradisional Kepanjen. Terdapat sejumlah 2 indikator yang didalamnya terdapat 10 pertanyaan yang digunakan dalam penelitian ini untuk mengukur variabel kualitas. Berikut skor rata rata indikator yang disajikan pada tabel 11 .

Tabel 3. Analisis Kualitas

\begin{tabular}{ccc}
\hline No & Indikator & Rata rata skor jawaban \\
\hline 1. & Kualitas baik & 4 \\
2. & Kualitas tidak baik & 2 \\
\hline
\end{tabular}

Sumber: Data Primer Diolah, Tahun 2020 
Tabel 3 menunjukan bahwa rata rata skor dari kedua indikator mendapat nilai 4 dan 2. Nilai rata rata skor menunjukan bahwa dari 88 responden penelitian, jawaban terbesar mereka atas pertanyaan dari indikator kualitas baik adalah (setuju) dan indikator dari kualitas tidak baik adalah (tidak setuju) atas dasar penilaian dari koesioner skala likert yang didapat dari rata rata jawaban responden, artinya responden mengakui bahwa indikator kualitas baik adalah (setuju) sedangkan indikator kualitas tidak baik adalah (tidak setuju). Variabel kualitas berhubungan dengan variabel kuantitas, apabila kualitas yang diberikan mampu membuat konsumen puas, maka dengan sendirinya konsumen akan membeli dengan jumlah atau kuantitas yang banyak. Kualitas akan mempengaruhi keputusan membeli karena kualitas merupakan salah satu jaminan yang harus diberikan dan dipenuhi oleh

Tabel 4. Analisis Tempat perusahaan kepada konsumen nya (Iswanto, M. Rambe, \& Ginting, 2013).

\section{Tempat}

Tempat merupakan suatu lokasi yang dipakai dalam sutau kegiatan, tempat dapat memberi pengaruh besar dalam kegiatan termasuk pasar. Menurut Trang \& Manampiring, (2016) place atau tempat merupakan gabungan antara lokasi dengan keputusan atas saluran distribusi, dalam hal, ini berhubungan dengan bagaimana cara penyampaian ke konsumen. Pemilihan lokasi mempunyai fungsi yang strategis karena dapat ikut menentukan tercapainya tujuan niaga. Tempat yang dimaksud dalam penelitian ini adalah pasar tradisional Kepanjen. Terdapat sejumlah 2 indikator yang didalamnya terdapat 10 pertanyaan yang digunakan dalam penelitian ini untuk mengukur variabel tempat. Berikut skor rata rata indikator yang disajikan pada tabel 12 .

\begin{tabular}{ccc}
\hline NO & Indikator & Rata rata skor jawaban \\
\hline 1. & Lokasi pasar & 4 \\
2. & Menarik dan tertata & 3 \\
\hline
\end{tabular}

Sumber: Data Primer Diolah, Tahun 2020

Tabel 4 menunjukan bahwa rata rata skor dari kedua indikator mendapat nilai 4 dan 3. Nilai rata rata skor menunjukan bahwa dari 88 responden penelitian, jawaban terbesar mereka atas pertanyaan dari indikator lokasi pasar adalah (setuju) dan indikator menarik dan tertata adalah (tidak tahu) atas dasar penilaian dari koesioner skala likert yang didapat dari rata rata jawaban responden, artinya responden mengakui bahwa lokasi pasar adalah baik, sedangkan indkator menarik dan tertata adalah tidak baik. lokasi pasar kepanjen tergolong strategis karena letaknya berada di tengah kota kecamatan. Variabel tempat juga digunakan pada penelitian yang dilakukan oleh (Haharap Ansary Dedy, 2015).

Tabel 5. Analisis pelayanan

\begin{tabular}{ccc}
\hline No & Indikator & Rata rata skor jawaban \\
\hline 1. & Penjual yang ramah & 4 \\
2. & Sarana umum pasar & 3 \\
\hline
\end{tabular}

Sumber: Data Primer Diolah, Tahun 2020

https://doi.org/10.32528/agribest.v4i2.3547 
Dari tabel di atas terlihat bahwa rata rata skor dari kedua indikator mendapat nilai 4 dan 3. Nilai rata rata skor menunjukan bahwa dari 88 responden penelitian, jawaban terbesar mereka atas pertanyaan dari indikator penjual yang ramah adalah (setuju) dan indikator sarana umum pasar (tidak tahu), atas dasar penilaian dari koesioner skala likert yang didapat dari rata rata jawaban responden, artinya responden mengakui bahwa penjual dipasar kepanjen ramah, sedangkan sarana umum pasar kurang baik. Pelayanan yang diberikan oleh seorang penjual akan sangat mempengaruhi minat dalam menentukan keputusan membeli.
Kuantitas

Kuantitas merupakan banyak atau sedikitnya produk atau hasil pertanian yang dibeli konsumen yang berbelanjan dipasar tradisional Kepanjen. Banyak atau sedikit yang yang akan di beli kemungkinan akan mempengaruhi komsumen dalam menentukan pembelian. Menurut Saraswati, Ribek, \& Mudana, (2018) kuantitas produk adalah suatu kemampuan perusahaan untuk memberikan identitas atau ciri pada setiap produknya sehingga konsumen dapat mengenali produk tersebut. Terdapat sejumlah 2 indikator yang didalamnya terdapat 10 pertanyaan yang digunakan dalam penelitian ini untuk mengukur variabel pelayanan. Berikut skor rata rata indikator yang disajikan pada tabel 14 .

Tabel 6. Analisis Kuantitas

\begin{tabular}{lll}
\hline NO & Indikator & Rata rata skor jawaban \\
\hline 1. & Membeli dengan jumlah sedikit & 3 \\
2. & Membeli dengan jumlah banyak & 3
\end{tabular}

Sumber: Data Primer Diolah, Tahun 2020

Dari tabel di atas terlihat bahwa rata rata skor dari kedua indikator mendapat nilai 3 dan 3 . Nilai rata rata skor menunjukan bahwa dari 88 responden penelitian, jawaban terbesar mereka atas pertanyaan dari indikator membeli dengan jumlah banyak adalah adalah (tidak tahu) dan indikator membeli dengan jumlah sedikit (tidak tahu), atas dasar penilaian dari koesioner skala likert yang didapat dari rata rata jawaban responden, artinya responden tidak tahu apakah dipasar akan membeli dengan jumlah sedikit atau banyak, hal ini tergantung kebutuhan atau kondisional.

Tabel 7. Analisis Keputusan Membeli

\begin{tabular}{cll}
\hline NO & Indikator & $\begin{array}{l}\text { Rata rata } \\
\text { skor } \\
\text { jawaban }\end{array}$ \\
\hline 1. & $\begin{array}{l}\text { Sesuai } \\
\text { dengan } \\
\text { kebutuhan }\end{array}$ & 4 \\
\hline
\end{tabular}

Sumber: Data Primer Diolah, Tahun 2020

Dari tabel diatas dapat dilihat bahwa rata skor dari indikator sesuai kebutuhan mendapat nilai 4 yang berarti rata rata jawaban responden dari pertanyan koesioner yang dibuat adalah (setuju), atas dasar penilaian dari koesioner skala likert, artinya responden membeli komoditi pertanian

\section{Keputusan Membeli}

Keputusan membeli adalah hasil ahir atas banyak nya pertimbangan yang telah dilakukan sebelum menentukan pilihan. Keputusan membeli dalam penelitian ini merupakan keputusan yang dilakukan oleh responden penelitian dalam menentukan pilihannya untuk berbelanjan komoditi hasil pertanian di pasar tradisional Kepanjen. Terdapat sejumlah 1 indikator yang didalamnya terdapat 5 pertanyaan yang digunakan dalam penelitian ini untuk mengukur variabel pelayanan. Berikut skor rata rata indikator yang disajikan pada tabel 15.

dipasar tradisonal sesuai dengan kebutuhan. Dari berbagai tempat dan jenis komoditi pertanian yang dijual konsumen harus mampu menentukan pilihanya, hal ini sesuai dengan pendapat Agustini, (2017) bahwa keputusan membeli merupakan suatu keputusan seseorang dimana dia memilih salah satu dari beberapa alternatif pilihan yang ada dalam memenuhi kebutuhannya.

\section{Uji Validitas dan Reliabilitas}

Uji validitas $r$ hitung dari keseluruhan pertanyaan dari variabel (X) maupun variabel (Y) lebih besar dari pada $r$ tabel maka dapat disimpulkan semua data 
valid. Nilai Cronbach's Alpha ( $\mathrm{r}$ alpha) adalah lebih besar dari nilai $r$ tabel 0,216 maka dapat disimpulkan data reliabel. Hal ini berarti pertanyaan-pertanyaan yang ada dalam kuesioner penelitian ini dapat diandalkan.

\section{Uji Asumsi Klasik}

Berdasarkan pengujian menggunakan software SPSS version 20 menggunakan metode One-Sample Kolmogorov-Smirnov Test mendapatkan hasil nilai Asymp Sig sebesar 0,995 > 0,05 dari nilai tersebut dapat simpulkan bahwa model regresi tersebut telah memenuhi asumsi kenormalan atau nilai residual berdistribusi normal. Model regresi yang baik merupakan model yang mememiliki nilai berdistribusi normal, uji normalitas dilakukan pada masing masing variabel tetapi hanya pada nilai residualnya (Duli, 2019).

Tidak terdapat hubungan antara variabel independent $\mathrm{X} 1$ pendapatan, $\mathrm{X} 2$ produk, X3 kuantitas, X4 tempat, X5 pelayanan dan X6 kualitas. Penilian tersebut berdasarkan dari Melihat nilai tolerance : jika nilai tolerance > dari 0,10 maka artinya data tidak terjadi multikolienaritas atau melihat nilai $V I F$ : jika nilai VIF lebih kecil dari < 10,00 maka artinya data tidak terjadi multikolienaritas. Pada tabel diatas semua nilai tolerance yang ada lebih dari 0,10 dan Tabel 8. Persamaan Regresi

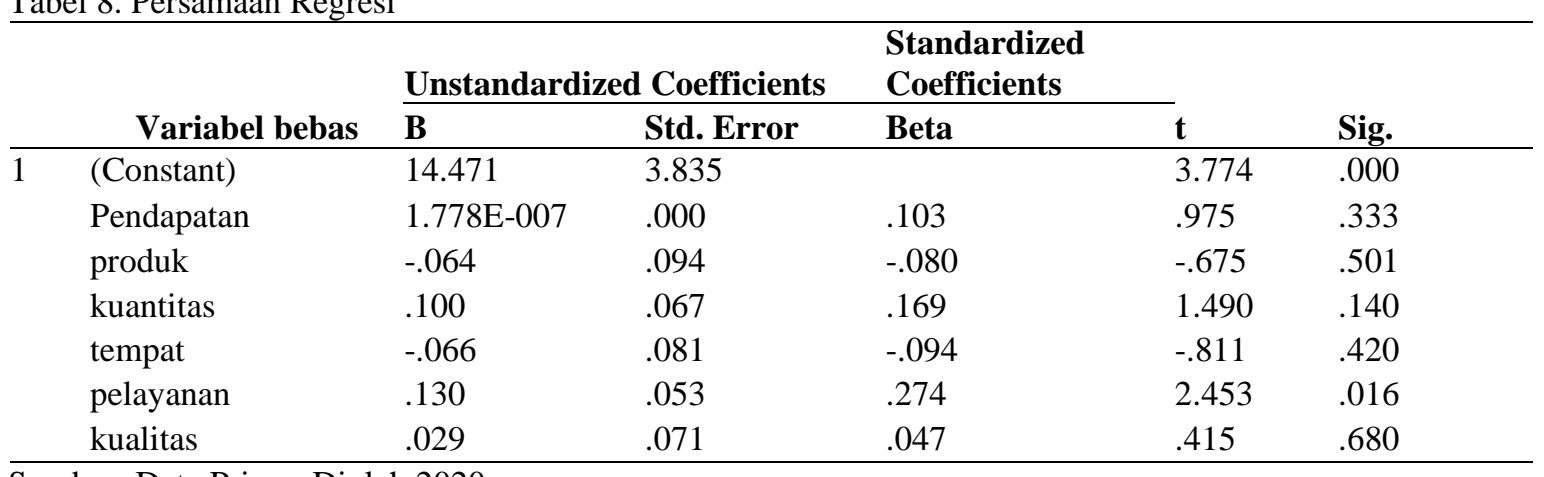

Sumber: Data Primer Diolah 2020

Adapun hasil persamaan regresi yang ada pada tabel 8 sebagai berikut :

$$
\begin{gathered}
Y=14,471+1,778 \mathrm{E}-7 \mathrm{X}_{1}+-0,064 \mathrm{X}_{2}+ \\
0,100 \mathrm{X}_{3}+-0,066 \mathrm{X}_{4}+0,130 \mathrm{X}_{5}+0,029 \mathrm{X}_{6}
\end{gathered}
$$

Dalam penelitian ini yang menjadi variabel terikat adalah keputusan pembelian (Y) yang nilainya akan diprediksi oleh oleh variabel bebas pendapatan $\left(\mathrm{X}_{1}\right)$, produk $\left(\mathrm{X}_{2}\right)$, https://doi.org/10.32528/agribest.v4i2.3547 nilai VIF kurang dari 10,00 yang memiliki makna data bebas dari gejala multikolieneritas. Suatu model regresi yang baik seharusnya bebas dari masalah multikolinearitas dan tidak terdapat korelasi antar variabel independen (walukow A.L.P \& Mananeke L, 2014).

Uji menggunakan metode Glejser dapat diperoleh nilai signifikasi semua variabel $\mathrm{x}$ atau independent memiliki nilai lebih dari 0,05. Dasar pengambilan keputusan nilai Jika nilai sig > 0,05 maka tidak terjadi heteroskedastisitas sebaliknya apabila nilai sig < 0,05 maka terjadi heteroskedatisitas. Data diatas menunjukan bahwa semua nilai Sig dari semua varibel lebih besar dari 0,05 yang artinya tidak ada gejala heteroskedastisitas.

\section{Hasil Analisis Regresi Linear Berganda}

Analisis regresi linear berganda memiliki fungsi untuk menganalisis hubungan dan pengaruh antara satu varibel terikat $(\mathrm{Y})$ terhadap variabel bebas $(\mathrm{X})$ yang lebih dari satu, selanjutnya dilakukan analisis regresi linear berganda antara variabel variabel ini : pendapatan $\left(\mathrm{X}_{1}\right)$, produk $\left(\mathrm{X}_{2}\right)$, kuantitas $\left(\mathrm{X}_{3}\right)$, tempat $\left(\mathrm{X}_{4}\right)$, pelayanan $\left(\mathrm{X}_{5}\right)$ dan kualitas $\left(\mathrm{X}_{6}\right)$ terhadap keputusan membeli (Y). Ini merupakan tabel hasil pengolahan data menggunakan program SPSS 21 didapatkan data sebagai berikut: kuantitas $\left(\mathrm{X}_{3}\right)$, tempat $\left(\mathrm{X}_{4}\right)$, pelayanan $\left(\mathrm{X}_{5}\right)$ dan kualitas $\left(\mathrm{X}_{6}\right)$. Persamaan regresi linear berganda tersebut di atas dapat menerangkan bahwa;

1) Konstanta sebesar 14.471 menyatakan bahwa apabila tidak ada variabel X maka keputusan membeli adalah 14.471 asumsi faktor lain kosntan.

2) Pengaruh pendapatan $\left(X_{1}\right)$ terhadap keputusan membeli komoditas hasil 
pertanian dipasar tradisonal Kepanjen dari hasil analisis nilai koefesien regresi sebesar 1.778E-7 yang menunjukan tanda positif yang menunjukan bahwa semakin meningkat pendapatan maka akan memberikan peningkatan terhadap keputusan pembelian.

3) Pengaruh produk $\left(X_{2}\right)$ terhadap keputusan membeli komoditas hasil pertanian dipasar tradisonal Kepanjen dari hasil analisis nilai koefesien regresi sebesar 0,064 yang memiliki nilai atau tanda negativ yang memiliki arti bahawa setiap perubahan $1 \%$ produk akan mempengaruhi keputusan pembelian.

4) Pengaruh kuantintas $\left(X_{3}\right)$ terhadap keputusan membeli komoditas hasil pertanian dipasar tradisonal Kepanjen dari hasil analisis nilai koefesien regresi sebesar 0,100 memiliki tanda atau nilai positif yang memiliki arti bahwa setiap perubahan $1 \%$ semakin meningkat kuantitas akan memberikan perngaruh terhadap keputusan pembelian.

5) Pengaruh tempat $\left(X_{4}\right)$ terhadap keputusan membeli komoditas hasil pertanian dipasar tradisonal Kepanjen dari hasil analisis nilai koefesien regresi sebesar 0,066 yang memiliki nilai atau tanda negativ yang memiliki arti bahawa setiap perubahan $1 \%$ tempat akan mempengaruhi keputusan pembelian.

6) Pengaruh pelayan $\left(\mathrm{X}_{5}\right)$ terhadap keputusan membeli komoditas hasil pertanian dipasar tradisonal Kepanjen dari hasil analisis nilai koefesien regresi sebesar 0,130 memiliki tanda atau nilai positif yang memiliki arti bahwa setiap perubahan $1 \%$ semakin meningkat pelayanan akan memberikan perngaruh terhadap keputusan pembelian.

7) Pengaruh kualitas $\left(\mathrm{X}_{6}\right)$ terhadap keputusan membeli komoditas hasil pertanian dipasar tradisonal Kepanjen dari hasil analisis nilai koefesien regresi sebesar 0,029 memiliki tanda atau nilai positif yang memiliki arti bahwa setiap perubahan $1 \%$ semakin meningkat pelayanan akan memberikan perngaruh terhadap keputusan pembelian.

\section{Koefesien Determinasi}

Tingkat ketepatan suatu garis dapat diketahui dari besar kecilnya koefesien determinasi atau koefesien $\mathrm{R}^{2}$ ( $\mathrm{R}$ Square). Nilai koefesien $R^{2}$ pada analalisis regresi dapat digunakan sebagai ukuran untuk menyatakan kecocokan garis regresi yang telah diperoleh. Semakin besar nilai $\mathrm{R}^{2}$ maka semakin kuat kemampuan model regresi yang didapat untuk menjelaskan kondisi yang sebenarnya. Koefesien determinasi $\mathrm{R}^{2}$ dari hasil regresi linear berganda menunjukan seberapa besar variabel dependen (keputusan membeli) dipengaruhi oleh variabel independent pendapatan $\left(\mathrm{X}_{1}\right)$, produk $\left(\mathrm{X}_{2}\right)$, kuantitas $\left(\mathrm{X}_{3}\right)$, tempat $\left(\mathrm{X}_{4}\right)$, pelayanan $\left(\mathrm{X}_{5}\right)$ dan kualitas $\left(\mathrm{X}_{6}\right)$. Berikut merupakan tabel hasil uji dari koefesien determinasi:

Tabel 9. Koefesien Determinasi

Model Summary

Std. Error of the

\begin{tabular}{lllll} 
Model & $\mathrm{R}$ & $\mathrm{R}$ Square & Adjusted R Square & Estimate \\
\hline 1 & $.339^{\mathrm{a}}$ & .115 & .050 & 1.759 \\
\hline
\end{tabular}

Sumber: Data Primer Diolah 2020

Berdasarkan tabel diatas hasil koefesien determinasi $\mathrm{R}^{2}$ sebesar 0,115 atau $11,5 \%$ hal ini menunjukan $11,5 \%$ keputusan membeli komoditas pertanian di pengaruhi oleh variabel pendapatan, produk, kuantitas, tempat, pelayanan, dan kualitas artinya memiliki hubungan kurang kuat. Sedangkan $88,5 \%$ dipengaruhi oleh variabel lain yang tidak dimasukan dalam model penelitian ini.

\section{Uji F Anova}

Uji F merupakan uji yang dilakukan secara simultan atau bersama sama untuk mengetauhi apakah semua variabel bebas yang terdiri dari pendapatan $\left(\mathrm{X}_{1}\right)$, produk $\left(\mathrm{X}_{2}\right)$, kuantitas $\left(\mathrm{X}_{3}\right)$, tempat $\left(\mathrm{X}_{4}\right)$, pelayanan $\left(\mathrm{X}_{5}\right)$ dan kualitas $\left(\mathrm{X}_{6}\right)$ memiliki pengaruh yang signifikan secara simultan terhadap 
variabel terikat yaitu keputusan membeli (Y). Uji F dilakukan dengan cara membandingkan nilai sig 0,15 atau batas kesalahan. Tabel 10. Hasil Uji F

\begin{tabular}{lrrrrr}
\hline \multicolumn{7}{c}{ ANOVA } & & & \\
\hline \multicolumn{1}{c}{ Model } & Sum of Squares & df & Mean Square & f & Sig \\
\hline Regresion & 32.595 & 6 & 5.432 & 1.755 & 0,119 \\
Residual & 250.678 & 81 & 3.095 & & \\
\hline Total & 283.273 & 87 & & & \\
\hline
\end{tabular}

Didapatkan hasil uji f yang disajikan pada tabel 23 sebagai berikut:

Sumber: Data Primer Diolah 202

Tabel 22 diatas menunjukan bahwa nilai signifikan sebesar $0,119<0,15$ maka hipotesis diterima artinya terdapat pengaruh secara simultan antara variabel bebas, pendapatan $\left(\mathrm{X}_{1}\right)$, produk $\left(\mathrm{X}_{2}\right)$, kuantitas $\left(\mathrm{X}_{3}\right)$, tempat $\left(\mathrm{X}_{4}\right)$, pelayanan $\left(\mathrm{X}_{5}\right)$ dan kualitas $\left(\mathrm{X}_{6}\right)$ terhadap keputusan membeli (Y).

\section{Uji t}

Uji $\mathrm{t}$ atau pengujian model regresi secara parsial dilakukan untuk mengetahui apakah masing masing variabel independen pembentuk model regresi secara parsial atau individu memiliki pengaruh yang signifikan terhadap variabel $\mathrm{Y}$ atau tidak. Hasil pengujian model regresi pada penelitian ini dapat dilihat pada tabel 24 sebagai berikut

Tabel 11. Uji t

\begin{tabular}{lrrrl}
\hline \multicolumn{1}{c}{ Variabel bebas } & Koefesien Regresi & \multicolumn{1}{c}{ thitung $_{\text {r }}$} & Sig. & Keterangan \\
\hline (Constant) & 14.471 & 3.774 & 0,000 & \\
pendapatan & $1.778 \mathrm{E}-7$ & 0,975 & 0,333 & Tidak Signifikan \\
produk & -.064 & -0.675 & 0,501 & Tidak Signifikan \\
kuantintas & .100 & 1,490 & 0,140 & Signifikan \\
tempat & -.066 &,- 0811 & 0,420 & Tidak Signifikan \\
pelayanan & .130 & 2,453 & 0,016 & Signifikan \\
kualitas & .029 & 0,415 & 0,680 & Tidak Signifikan \\
\hline
\end{tabular}

Sumber: Data Primer Diolah 2020

Berdasarkan tabel 23 dapat diketahui bahwa uji $t$ dilakukan dengan cara membandingan nilai sig, apabila nilai sig kurang dari 0,15 maka Ho ditolak dan ha diterima. Uji t menunjukan bahwa ada 2 variabel independen yang memiliki nilai sig kurang dari 0,15 yang memiliki makna berpengaruh terhadap keputusan membeli.

1) Pendapatan (X1)

Variabel pendapatan (X1) memiliki nilai tingkat signifikasi $0,333>0,15$ maka Ho diterima dan Ha ditolak dengan demikian maka pendapatan tidak berpengaruh positif dan signifikan terhadap keputusan membeli komoditas pertanian dipasar tradisional Kepanjen.

2) Produk (X2)

Variabel produk (X2) memiliki nilai tingkat signifikasi $0,501>0,15$ maka Ho diterima dan Ha ditolak dengan demikian maka produk tidak berpengaruh positif dan signifikan terhadap keputusan membeli komoditas pertanian dipasar tradisional Kepanjen.
3) Kuantitas (X3)

Variabel kuantitas (X3) memiliki nilai tingkat signifikasi $0,140>0,15$ maka Ho ditolah dan Ha diterima dengan demikian maka kuantitas berpengaruh positif dan signifikan terhadap keputusan membeli komoditas pertanian dipasar tradisional Kepanjen.

4) Tempat (X4)

Variabel (X4) memiliki nilai tingkat signifikasi $0,420>0,15$ maka Ho diterima dan Ha ditolak dengan demikian maka tempat tidak berpengaruh positif dan signifikan terhadap keputusan membeli komoditas pertanian dipasar tradisional Kepanjen.

5) Pelayanan (X5)

Pelayanan (X5) memiliki nilai tingkat signifikasi 0,016>0,15 maka Ho ditolak dan Ha diterima dengan demikian maka pelayanan berpengaruh positif dan signifikan terhadap keputusan membeli komoditas pertanian dipasar tradisional Kepanjen. 
6) Kualitas (X6)

Kualitas (X6) ) memiliki nilai tingkat signifikasi $0,680>0,15$ maka Ho diterima dan $\mathrm{Ha}$ ditolak dengan demikian maka kualitas tidak berpengaruh positif dan signifikan terhadap keputusan membeli komoditas pertanian dipasar tradisional Kepanjen.

\section{Pembahasan}

Penelitian ini dilakukan dengan tujuan untuk mengetahui faktor produk, pendapatan, kuantitas, tempat, pelayanan dan kualitas terhadap keputusan membeli komoditas pertanian dipasar tradisional Kepanjen.

\section{Faktor pendapatan terhadap keputusan membeli komoditi pertanian}

Hasil penelitian menujukan bahwa variabel pendapatan memiliki nilai signifikasi sebesar $0,333>0,15$ dengan nilai koefesien sebesar $1.778 \mathrm{E}-7$ yang artinya berpengaruh positif tetapi tidak signifikan atau pendapatan tidak berpengaruh terhadap keputusan membeli komoditas pertanian.

Pendapatan seorang responden pada penelitian ini memang tidak berpengaruh signifikan tetapi memiliki nilai koefesien yang positif terhadap keputusan membeli komoditas pertanian. Artinya faktor variabel pendapatan searah dengan keputusan membeli, jika pendapatan seseorang semakin tinggi maka akan meningkat juga terhadap keputusan membeli komoditas pertanian, begitu juga sebaliknya.

Menurut Eliza et.al (2011) pendapatan mempengaruhi keputusan seseorang menentukan tempat membeli, namun hal ini tidak berlaku untuk semua orang, sebagian konsumen menentukan tempat membeli berdasarkan tawaran harga yang murah, tetapi tidak sedikit konsumen yang mengginkan kenyamanan dalam berbelanja walaupun harga yang ditawarkan lebih tinggi.

Hasil penelitian ini memperkuat penelitian terdahulu yang dilakukan oleh Laksono \& Iskandar, (2018) dengan judul pengaruh gaya hidup dan pendapatan terhadap keputusan membeli helm kbc. Hasil penelitian ini membuktikan bahwa gaya hidup berpengaruh secara signifikan sedangkan pendapatan tidak berpengaruh terhadap keputusan membeli helm kbc.

\section{Faktor produk terhadap keputusan membeli komoditi pertanian}

Hasil penelitian ini menunjukan bahwa variabel produk memiliki nilai signifikasi sebesar 0,501>0,15 dengan nilai koefesien sebesar -0.064 yang artinya tidak berpengaruh positif dan tidak signifikan terhadap keputusan membeli. Tanda negatif dari koefesien regresi berlawanan dengan point produk, nilai koefesien regresi menunjukan apabila produk meningkat satu satuan maka skor keputusan membeli minimum akan turun sebesar 0,064 dengan asumsi variabel yang lain tetap. Artinys apabila produk meningkat satu level, maka keputusan membeli akan semakin menurun.

Keberagaman produk merupakan sesuatu yang harus dipenuhi, menurut Pardede \& Haryadi, (2017) keberagaman produk menyatakan bahwa kelengkapan produk menyangkut lingkup layanan dan ketersediaan sarana pendukungnya. Produk sendiri meliputi barang barang yang dijual dan ditawarkan oleh peritel dimana produk tersebut berpengaruh pada citra toko atau penjual yang ada. Semakin banyak aneka produk yang ditawarkan akan memberi kepuasan tersendiri bagi konsumen.

Hasil penelitian ini sesuai dengan penelitian yang dilakukan oleh Rawung, Oroh, \& Sumarauw, (2015) dan Aziz, (2019), penelitian ini membuktikan bahwa produk tidak berpengaruh terhadap keputusan membeli. Peningkatan produk perlu dilakukan agar memberi kepuasan dan berdampak terhadap keputusan membeli.

\section{Faktor kuantitas terhadap keputusan membeli komoditi pertanian}

Hasil penelitian ini menunjukan bahwa variabel kuantitas memiliki nilai signifikasi sebesar $0,14<0,15$ berpengaruh signifikan terhadap keputusan membeli komoditas pertanian, dan nilai koefesien regresi sebesar 0,100 yang memiliki tanda positif yang searah dengan keputusan membeli. Koefesien regresi menunjukan apabila kuantitas meningkat satu satuan maka skor keputusan membeli akan meningkat sebesar 0,100 dengan asumsi variabel yang lain tetap artinya semakin banyak kuantitas yang dibutuhkan akan meningkatkan keputusan membeli. 
Faktor kedua yang mempengaruhi konsumen dalam membeli komoditas pertanian adalah faktor kuantitas. Kuantitas atau banyak sedikit jumlah yang akan dibeli konsumen sangat mempengaruhi dalam keputusan membeli. Pasat tradisonal kepanjen menyediakan komoditas pertanian dengan jumlah yang banyak, hal ini menyebabkan konsumen berbelanja dengan jumlah yang tidak sedikit, dengan tujuan untuk persediaan.

Hasil penelitian ini memperkuat dengan penelitian terdahulu yang dilakukan oleh Aisha \& Kurnia, (2018) dengan judul Pengaruh Kuantitas Pelayanan dan Kualitas Pelayanan terhadap Citra Merek. Penelitian ini membuktikan bahwa kuantitas sangat mempengaruhi keputusan membeli.

\section{Faktor tempat terhadap keputusan membeli komoditi pertanian}

Hasil penelitian ini menunjukan bahwa variabel tempat memiliki nilai signifikasi sebesar $0,420>0,15$ dan nilai koefesien regresi sebesar $-0,066$ yang artinya tidak signifikan dan memiliki tanda negatif. Tanda negatif dari koefesien regresi berlawanan dengan point tempat, nilai koefesien regresi menunjukan apabila tempat meningkat satu satuan maka skor keputusan membeli minimum akan turun sebesar 0,066 dengan asumsi variabel yang lain tetap. Artinya apabila tempat meningkat satu level, maka keputusan membeli akan semakin menurun.

Tempat bisa menjadi salah satu faktor yang mempengaruhi konsumen dalam berbelanja, namun masih banyak faktor lain yang seperti pelayanan dan kuantitas. Menurut walukow A.L.P \& Mananeke L, (2014) lokasi Lokasi adalah tempat, kedudukan secara fisik yang mempunyai fung.si strategis karena dapat ikut menentukan tercapainya tujuan badan usaha. Tempat diartikan sebagai saluran distribusi untuk produk industri manufaktur sedangkan lokasi diartikan sebagai tempat jual beli, pelayanan jasa untuk produk industri jasa.

Hasil penelitian ini senada dengan penelitian terdahulu yang dilakukan oleh Trang \& Manampiring, (2016) dengan judul pengaruh produk, harga, promosi dan tempat terhadap keputusan pembelian mobil di pt. astra international tbk malalayang. Penelitian ini membuktikan bahwa varibel tempat tidak https://doi.org/10.32528/agribest.v4i2.3547 berpengaruh signifikan terhadap keputusan pembelian.

\section{Faktor pelayanan terhadap keputusan membeli komoditi pertanian}

Hasil penelitian ini menunjukan bahwa variabel pelayan memiliki nilai signifikasi sebesar 0,016 dengan nilai koefesien regresi sebesar 0,130 yang memiliki tanda positif yang searah dengan keputusan membeli. Koefesien regresi menunjukan apabila pelayanan meningkat satu satuan maka skor keputusan membeli akan meningkat sebesar 0,130 dengan asumsi variabel yang lain tetap artinya semakin miningkat kualitas pelayanan akan meningkatkan keputusan membeli.

Kegiatan jual beli banyak di pengaruhi suatu hal salah satunya adalah faktor pelayanan. Pelayanan dalam hal apapun yang diberikan pedagang atau produsen sangat mempengaruhi kondisi emosional kunsumen. Pelayanan yang baik akan mampu membuat konsumen menjadi pelangan, dengan menjadi pelangan secara tidak langsung membuktikan bahwa seorang penjual telah memberikan pelayanan yang terbaik dan memberi kepuasan kepada konsumen. Menurut Sinambow \& Trang, (2015) definisi kualitas layanan berpusat pada upaya pemenuhan kebutuhan dan keinginan pelanggan serta ketepatan penyampaiannya untuk mengimbangi harapan pelanggan. kualitas layanan adalah tingkat keunggulan yang diharapkan dan pengendalian atas tingkat keunggulan tersebut untuk memenuhi keinginan pelanggan.

Hasil penelitian memiliki memperkuat penelitian terdahulu yang dilakukan oleh Weenas, (2013), kodu sarini, (2013), (Fure, 2013) dan Widowati \& Purwanto, (2014) penelitian ini membuktikan bahwa varibel pelayanan sangat mempengaruhi keputusan pembelian.

\section{Faktor kualitas terhadap keputusan membeli komoditi pertanian \\ Hasil penelitian ini menunjukan} bahwa variabel kualitas memiliki nilai signifikasi sebesar $0,680>0,15$ dan nilai koefesien regresi sebesar 0,029 tanda positif. Maka hasil penelitian ini membuktikan bahwa variabel kualitas berpengaruh positif tetapi tidak terdapat pengaruh secara 
signifikan terhadap keputusan membeli komoditas pertanian dipasar tradisional Kepanjen. Tanda positif pada nilai koefesien regresi memiliki arti bahwa variabel kualitas searah dengan keputusan membeli, apabila kualitas dari komoditas pertanian meningkat maka akan meningkatkan keputusan membeli komoditas pertanian tersebut.

Kualitas yang baik suatu produk maupun jasa sangatlah diharapkan khususnya sebagai konsumen. Kualitas produk yang baik akan mampu mempengaruhi kondisi lingkungan tersebut, Seperti halnya jika seseorang puas dengan kualitas produk tersebut mereka akan menceritakan apa yang didapatkannya kepada teman keluarga serta lingkungan tempat tinggal, hal ini akan sangat mempengaruhi dan meningkatkan keputusan membeli. Menurut Widyastuti, (2018) kualitas produk merupakan salah satu faktor yang diperhatikan konsumen dalam membeli suatu produk. Kualitas adalah keseluruhan ciri-ciri dan karakteristik dari suatu barang atau jasa, dalam hal kemampuan untuk memenuhi kebutuhan-kebutuhan yang telah di tentukan atau bersifat laten. Hasil penelitian menunjukan bahwa kualitas produk yang ditawarkan tergolong baik dan berkualitas, meliputi keawetan atau ketahanannya, kualitas desain atau bentuknya, kualitas warna, kualitas kelengkapan perlengkapan, hal tersebut menjadikan pertimbangan konsumen dalam melakukan pembelian.

Hasil penelitian ini sama dengan penelitian terdahulu yang dilakukan oleh Aziz, (2019) dengan judul analisis Pengaruh Kualitas Produk, Harga, Promosi Terhadap Keputusan Pembelian Air Minum Dalam Kemasan (Amdk) Merek Aicos Produksi Pt. Bumi Sarimas Indonesia, bahwa kualitas tidak berpengaruh terhadap keputusan membeli.

\section{KESIMPULAN}

Kesimpulan dan saran dari penelitian ini adalah sebagai berikut 1). Hasil uji $F$ menunjukan bahwa pendapatan (X1), produk (X2), kuantitas (X3), tempat (X4), pelayanan (X5) dan kualitas (X6) secara bersama sama berpengaruh terhadap keputusan membeli (Y) dengan tingkat nilai signifikasi 0,119 < 0,15. 2) Hasil uji $T$ menunjukan bahwa variabel tempat (X4) secara parsial tidak berpengaruh positif terhadap keputusan https://doi.org/10.32528/agribest.v4i2.3547 membeli. Hal ini dibuktikan dengan nilai tingkat signifikasi $0,420>0,15$ tidak berpengaruh terhadap keputusan membeli komoditas pertanian dipasar tradisonal Kepanjen. 3) Dari beberapa variabel, variabel pelayanan yang memiliki nilai paling berpengaruh, penelitian ini mendapatkan hasil bahwa faktor pelayananlah yang memiliki pengaruh paling besar dengan nilai tingkat signifikasi $0,016<0,15$. Beberapa saran yang dapat disampaikan penulis terhadap pihak pihak terkait sebagai berikut, 1) Kepada peneliti selanjutnya diharapkan untuk menambahkan variabel yang lain dan menambah jumlah responden penelitian. 2). Kepada peneliti selajutnya agar memfokuskan hanya beberapa komiditi pertanian agar cakupan pembahasan tidak terlalu luas.

\section{DAFTAR PUSTAKA}

Agustini, N. K. D. A. (2017). Analisis Faktor-Faktor Yang Mempengaruhi Keputusan Membeli Di Online Shop Mahasiswa Jurusan Pendidikan Ekonomi Angkatan Tahun 2012. Jurnal Pendidikan Ekonomi Undiksha, 9(1), 127. https://doi.org/10.23887/jjpe.v9i1.1999 7

Aisha, N., \& Kurnia, E. (2018). Pengaruh Kuantitas Pelayanan dan Kualitas Pelayanan terhadap Citra Merek pada Universitas Muhammadiyah Sumatera Utara. Jurnal Samudra Ekonomi Dan Bisnis, 9(2), 128-137. https://doi.org/10.33059/jseb.v9i2.761

Arianty, N. (2013). Analisis Perbedaan Pasar Modern Dan Pasar Tradisional Ditinjau Dari Strategi Tata Letak (Lay Out) Dan Kualitas Pelayanan Untuk Meningkatkan Posisi Tawar Pasar Tradisional. Jurnal Manajemen \& Bisnis, 13(01), 12.

Arikunto s. (2013). Prosedur Penelitian Suatu Pendekatan Praktek. jakarta: Rineka Cipta.

Aziz, N. (2019). Analisis Pengaruh Kualitas Produk, Harga, Promosi Terhadap Keputusan Pembelian Air Minum Dalam Kemasan (Amdk) Merek Aicos Produksi Pt. Bumi Sarimas Indonesia. 
1-9.

https://doi.org/10.31219/osf.io/w6dt5

Duli, N. (2019). Metodologi Penelitian Kuantitatif: Beberapa konsep Dasar Untuk Penulisan Skripsi Dan Analisis Data Dengan Spss (edisi pert). Yogyakarta.

Dwimawanti, ida hayu. (2004). (Salah Satu Parameter Keberhasilan Otonomi Daerah) Oleh : Ida Hayu Dwimawanti. 2004, 109-116. Retrieved from http://eprints.walisongo.ac.id/3684/

Eliza, Sayamar, E., \& Kaswita, C. (2011). Analisis Faktor-Faktor Yang Mempengaruhi Konsumen Dalam Pengambilan Keputusan Pembelian Buah Di Pasar Arengka ( Pasar Tradisional Dan Giant Hypermarket (Pasar Modren) Di Kecamatan Tampan Kota Pekanbaru. Indonesian Journal Of Agricultural Economics(IJAE), 2(1), 15-34.

Fure, H. (2013). Lokasi, Keberagaman Produk, Harga, Dan Kualitas Pelayanan Pengaruhnya Terhadap Minat Beli Pada Pasar Tradisional Bersehati Calaca. Journal of Clinical Oncology, 32(27), 3083.

https://doi.org/10.1200/JCO.2014.56.85 01

Ghozali, I. (2005). Aplikasi Analisis Multavariate dengan program SPSS. Semarang: UNDIP.

Haharap Ansary Dedy. (2015). Analisis faktor-faktor yang mempengaruhi keputusan pembelian konsumen di pajak usu (pajus) medan. Jurnal Keuangan Dan Bisnis, 7(3).

Hair, J. . (2006). Multivariate Data Analysis. Jakarta: Gramedia Pustaka Utama.

Ibrahim, J. T. (1999). Diktat Metode Penelitian Sosial Ekonomi Pertanian. Malang: Jurusan Agribisnis Fakultas Pertanian Peternakan. Universitas Muhammadiyah Malang. Malang.

Idris, I., Sari, R. A., Wulandari, W., \& U, W. (2016). Pengendalian Kualitas Tempe Dengan Metode Seven Tools.
Teknovasi, 3(1), 66-80.

Iswanto, A., M. Rambe, A., \& Ginting, E. (2013). Aplikasi Metode Taguchi Analysis Dan Failure Mode and Effect Analysis (Fmea) Untuk Perbaikan Kualitas Produk Di Pt. Xyz. Jurnal Teknik Industri USU, 2(2), 13-18.

kodu sarini. (2013). Harga, Kualitas Produk Dan Kualitas Pelayanan Pengaruhnya Terhadap Keputusan Pembelian Mobil Toyota Avanza. Jurnal Emba, 1(3), 1251-1259.

https://doi.org/10.1002/pola.21914

Kurriwati, N. (2016). Pengaruh Kualitas Produk Terhadap Kupuasan dan Dampaknya Terhadap Loyalitas Konsumen. Jurnal Manajemen Pemasaran Petra, 1(1), 48-55. Retrieved from http://journal.trunojoyo.ac.id/ecoentrepreneur/article/view/994/893

Laksono, D. D., \& Iskandar, D. A. (2018). Pengaruh Gaya Hidup Dan Pendapatan Terhadap Keputusan Pembelian Helm Kbc. Jurnal Riset Manajemen Dan Bisnis (JRMB) Fakultas Ekonomi UNIAT, 3(2), 145-154. https://doi.org/10.36226/jrmb.v3i2.113

Noor, W. S., \& Ikasari, H. (2010). Analisis Faktor-Faktor Yang Mempengaruhi Konsumen Dalam Pengambilan Keputusan Pembelian Sayuran Di Pasar Tradisional Di Kota Semarang. Manajemen Fakultas Ekonomi Dan Bisnis Universitas Dian Nuswantoro, (1), 12.

Pardede, R., \& Haryadi, T. Y. (2017). Pengaruh Persepsi Harga Dan Kualitas Produk Terhadap Keputusan Pembelian Konsumen Yang Dimediasi Kepuasan Konsumen. Journal of Business \& Applied Management, 10(1). https://doi.org/10.30813/jbam.v10i1.87 0

Perdana, E. (2016). Olah Data Skripsi Dengan SPSS 22. Bangka Belitung: Lab Kom Manajemen Fe Ubb Redaksiy.

Rawung, D. R., Oroh, S., \& Sumarauw, J. S. 
(2015). Analisis Kualitas Produk, Merek Dan Harga Terhadap Keputusan Pembelian Sepeda Motor Suzuki Pada Pt. Sinar Galesong Pratama Manado. Jurnal Riset Ekonomi, Manajemen, Bisnis Dan Akuntansi, 3(3), 1298-1308.

Saodah, D. S., \& Malia, R. (2017). FaktorFaktor Yang Mempengaruhi Konsumen dalam Pembelian Sayuran di Pasar Tradisional ( Studi Kasus Pasar Muka Cianjur ). Journal Agroscience Vol. 7 No. 1 Tahun 2017, 7(2579-7891), 178193.

Saraswati, N. P. A. S., Ribek, P. K., \& Mudana, W. (2018). Program Pengabdian Kepada Masyarakat Melalui Peningkatan Kualitas Dan Kuantitas Produksi Patung Berbasis Limbah Di Desa Singapadu, Gianyar, Bali. SELAPARANG Jurnal Pengabdian Masyarakat Berkemajuan, 2(1), https://doi.org/10.31764/jpmb.v2i1.555

Sinambow, S., \& Trang, I. (2015). Pengaruh Harga, Lokasi, Promosi Dan Kualitas Layanan Terhadap Keputusan Pembelian Pada Toko Komputer Game Zona Mega Mall Manando. Emba Issn 2303-11, 3(3), 300-311.

Sudjana. (2001). Metode \& Teknik Pembelajaran Partisipatif. Bandung. Bandung: Falah Production.

Sugiyono. (2017). Metode Penelitian Kuantitatif, Kualitatif, dan $R \& D$. Bandung: Alfabeta, CV.

Suliyanto. (2005). Analisis Data dalam Aplikasi Pemasaran. Bogor: Ghalia Indonesia.

Sunarto. (2018). Analisis Perilaku Konsumen Terhadap Keputusan Pembelian Handphone Xiaomi Redmi 3S. Jurnal Moneter, V(1), 35-43.
Trang, I., \& Manampiring, A. (2016). Pengaruh Produk, Harga, Promosi Dan Tempat Terhadap Keputusan Pembelian Mobil Di Pt. Astra International Tbk Malalayang. Jurnal Riset Ekonomi, Manajemen, Bisnis Dan Akuntansi, 4(1), 472-483.

walukow A.L.P, \& Mananeke L. (2014). Pengaruh Kualitas Produk, Harga, Promosi Dan Lokasi Terhadap Keputusan Pembelian Konsumen Di Bentenan Center Sonder Minahasa. Japanese Journal of Crop Science, 27(4), 467-468.

Weenas, J. (2013). Kualitas Produk, Harga, Promosi Dan Kualitas Pelayanan Pengaruhnya Terhadap Keputusan Pembelian Spring Bed Comforta. Jurnal Riset Ekonomi, Manajemen, Bisnis Dan Akuntansi, 1(4), 607-618. https://doi.org/10.35794/emba.v1i4.274 1

Widowati, M., \& Purwanto, A. B. (2014). Influence of Service Quality and Location Against Purchase Decision with Visual Merchandising as Moderating Variable (Study on Minimarket ALFAMART Semarang). Pengaruh Kualitas Pelayanan Dan Lokasi Terhadap Keputusan Pembelian Dengan Visual Marchandising Sebagai Variabel Moderating, 9(1), 65-80. https://doi.org/https://doi.org/10.34152/ fe.9.1.\%25p

Widyastuti, P. (2018). Kualitas dan Harga sebagai Variabel Terpenting pada Keputusan Pembelian Sayuran Organik. Ekspektra: Jurnal Bisnis Dan Manajemen, 2(1), 17. https://doi.org/10.25139/ekt.v2i1.675 